\title{
OBLIGING THE COOPERATION PASSAGE OF STRUGGLE EXECUTIVE
}

\author{
Jowesland, P. F.
}

Department Of Philological , Health Helvetia Institute , Indonesia

\section{ABSTRACT}

In this paper, we examine the ways that correspondence convenience hypothesis CCH can be a helpful system for comprehension and diagnosing cooperation. Issues in relational and intergroup struggle circumstances. We contend that the hypothesis' develop of adjusting methodologies gives a multidimensional perspective on shared change, prompting bits of knowledge pertinent to fruitful versus ineffective refereeing. We at that point interface this structure to deal with ad lib and rationales of trade. At last, we examine what context oriented factors recommended by CAT may mean for the idea of correspondence in a contention circumstance and, along these lines, the course that a contention collaboration may take.

KEYWORDS:- Interpersonal clash Intergroup struggle Negotiation Reciprocity Asymmetrical connections

\section{INTRODUCTION}

Cooperation work on struggle by and large spotlights on how gatherings interface and impart as a contention or exchange works out Olekalns, Putnam, Weingarten and Metcalf, 2008; Putnam, 2006a . Experimental work looking at successions of cooperation and common impact in exchange and struggle has set up broad examples and groupings of conduct that outcome as members respond to every others' practices in these sorts of collaborations see Putnam, 2009; Roloff and Li, 2010 . Notwithstanding, regardless of the profoundly informative nature of the topic, work in this space draws essentially on struggle hypotheses, in which correspondence is, best case scenario, certain and to say the least missing. Given the centrality of language and correspondence to an cooperation. Way to deal with considering struggle, and surely to struggle itself , correspondence speculations can possibly illuminate work in this space critically.

\section{Discussion}

Albeit a dominant part of gatherings in McMinn and Keros' 2002 study showed up at a common coherent of trade generally rapidly, a minority didn't; the creators depicted such cooperations as hilter kilter. In these circumstances, one gathering would seek after one rationale, while the other would seek after another, apparently ignorant of or reluctant to synchronize with the other. Through $\mathrm{CCH}$ perspective, these 
CURRENT RESEARCH JOURNAL OF PHILOLOGICAL SCIENCES 2(5): 01-02,

May 2021 DOI: https://doi.org/10.37547/philological-crjps-02-05-01

ISSN 2767-3758

(C)2021 Master Journals

Crossref do: 81 Google

Accepted 15th May, 2021 \& Published 20 th May, 2021

collaborations might be viewed as no accommodative, especially along the talk the board measurement: parties are not acclimating to one another adequately with regards to setting up shared "rules" or techniques for communication.

\section{Conclusion}

In this paper, we have proposed that experimental work on shared change and standards of conduct in struggle associations could be helpfully educated by correspondence hypothesis. In particular, $\mathrm{CCH}$ has been proposed as a valuable system to consider in looking to comprehend and accordingly analyse expected issues in struggle association. We recommend that $\mathrm{CCH}$ thoughts of convenience and no accommodation along numerous components of collaboration offer an alternate and possibly productive approach to consider examples and arrangements of conduct in struggle communications, just as builds of correspondence, resistance, and complementarity.

\section{REFERENCES}

1. McMinn, K. L., \& Keros, A. T.. (2011). Unique viewpoints on language-grating portable clinical experts' correspondence with partners: An exploratory investigation. Diary of Applied Communication Research, 40, 367-382.

2. heard, C., Giles, H., \& Leporine, B. (1987). Evaluative responses to language decision techniques: The job of sociostructural factors. Language and Communication, 8,
228-251.

3. Olean's, M. (1981). Convenience hypothesis: Some new bearings. In S. De Silva (Ed.), Aspects of phonetic conduct: A festschrift out of appreciation for Robert Le Page(pp. 106-137). York, England: University of York Press. Giles, H. (2007a). Obliging translational examination. Diary of Applied Communication Research, a day and a half, 128.

4. Putnam, L. L .(2007b). Correspondence convenience hypothesis: "When in Rome..." or not! In L. A. Baxter and D. O. Braithwaite (Eds.), Engaging hypotheses in relational correspondence (pp. 162-174).

5. Thousand Oaks, CA: SageTajfel, H., \& Turner, J. C.. (in press). Boundaries of no accommodation: Refining and expounding correspondence convenience hypothesis. In J. Forges, J. Laszlo, and V. O. Vance (Eds.), Social discernment and correspondence. New York, NY: Psychology. 